\title{
Parent's food preference and its implication for child malnutrition in Dabat health and demographic surveillance system; community-based survey using multinomial logistic regression model: North West Ethiopia; December 2017
}

Nigusie Birhan Tebeje ${ }^{1 *}$, Gashaw Andargie Biks², Solomon Mekonnen Abebe $^{3}$ and Melike Endris Yesuf ${ }^{3}$

\begin{abstract}
Background: A Shortage or excessive intake of the nutrient is malnutrition; affecting every aspect of human beings. Malnutrition at childhood has long-lasting and multiple effects. In Ethiopia significant numbers of children were suffering from malnutrition that might be associated with parents' food preference; the fact not yet investigated. Therefore the aim of this study was to assess parents' food preferences and its implication for child malnutrition.

Methods: The study was conducted among 7150 mothers/caretakers in Dabat demographic and health surveillance site. Data were collected by experienced data collectors working for the surveillance centers after extensive training. A multinomial logistic regression model was fitted to determine the effect of factors on the dependent variable and model fitness was checked using a likelihood ratio test.

Results: About $62.55 \%$ of mothers/caretakers prefer to feed children with a family and $16.45 \%$ of them prefer to feed children with a specific type of food. Mothers/caretakers who introduce semisolid food after 6 months 2.34(1.50-3.96) were times more likely prefer to feed with family food for their children than a balanced diet. Regarding the specific type of food preference mothers who introduce semisolid food after 6 months and those obtain food from the market were 6.53(3.80-11.24) and 4.38(3.45-5.56) times more likely to prefer to feed specific types of than balanced diet respectively.

Conclusion: Food preference had contributed to the increased and persistent magnitude of child malnutrition as $62.55 \%$ of mothers prefer to feed children with family and only $21 \%$ of them prefer to feed a balanced diet for under-five children. Therefore we recommended integration of child dietary diversity, acceptability and safety counseling session for mothers visiting health institutions for child vaccination, ANC and PNC services.
\end{abstract}

Keywords: Under-five, Children, Food preference, Dabat, Parent, Caretaker

\footnotetext{
* Correspondence: nigusiebirhan@gmail.com

${ }^{1}$ School of Nursing, College of Medicine and Health Sciences, University of

Gondar, Gondar, Ethiopia

Full list of author information is available at the end of the article
}

(c) The Author(s). 2019 Open Access This article is distributed under the terms of the Creative Commons Attribution 4.0 International License (http://creativecommons.org/licenses/by/4.0/), which permits unrestricted use, distribution, and reproduction in any medium, provided you give appropriate credit to the original author(s) and the source, provide a link to the Creative Commons license, and indicate if changes were made. The Creative Commons Public Domain Dedication waiver (http://creativecommons.org/publicdomain/zero/1.0/) applies to the data made available in this article, unless otherwise stated. 


\section{Background}

Malnutrition is a failure of the body to get an appropriate amount of nutrients for healthy human organ and tissue function. Children were more vulnerable to malnutrition. Children who suffer from nutritional deprivation were at risk of developmental delays which can lead to different consequences [1]. In the year 2007, the Lancet estimated that about 200 million under-five children were failing to fulfill developmental potential in developing countries due to malnutrition [2]. According to the MDG report in 2012 malnourished children at adulthood are estimated to earn $20 \%$ less than their counterparts [3]. The young lives survey in its 2010 report in developing countries suggests that by of age 7 or 8 years older the malnutrition consequence is comparable to a loss of full-term schooling and is associated with the loss of 10-15 IQ points $[4,5]$.

The global burden of diseases suggested that underweight in young children is one of the leading cause of burden of disease in sub-Saharan Africa. It is responsible for increased years of lives with a disability for children under 5 years [5]. In 2013 almost 6.3 million children under 5 years lost their life from preventable causes and every year about 2.6 million under-five children died because of malnutrition [6].

In the year 201110 years after setting the goal of eradicating extreme hunger globally about 314, 258, and 52 million children below the age of five were suffering from stunting, underweight and wasting respectively [7]. Malnutrition occurring in the first 1000 days of life has longlasting irreversible consequence including being stunting forever, susceptible to sickness, poor school performance, entering adulthood more likely to become overweight and prone to none communicable disease [8].

Malnutrition is a priority problem since the 1970 s but not addressed yet because it may be related to mothers/ caretakers food preference uninvestigated fact but have potential to affect safety, diversity, acceptability, and frequency of food basic dimensions for good nourishment of children [9]. Another nutrition-related emerging public health problem more prominently related to food preference is an increased rate of overweight and expected to nearly double again by 2025 but not yet investigated well in middle and low-income countries [10].

It is agreed on the fact that no child is born to die from the cycle of malnutrition and our world is believed to have enough food for every one of us [3]. However, currently available evidence on child malnutrition was limited to determine the prevalence of malnutrition and revealed that $40 \%$ of under-five children in the globe were experiencing hunger. On the contrary works in FAO shows that world agriculture can produce enough to feed humanity indicating that there is an uninvestigated fact that probably related to parental food preference. We hypothesize that mothers/caretakers food preference may be the main contributor for child malnutrition which negatively interacting-with quality, diversity, frequency, safety, acceptability, and quantity of food in addition to ensuring food security and healthcare [11, 12]. Therefore this study was intended to generate information on the parent/caretakers food preference and its implication for child malnutrition in Dabat health and demographic site for national, regional and local decision-makers.

\section{Methods}

Study area

Study was conducted in Dabat district among 13 kebeles included in Dabat Demographic and Health Surveillance system site (DHSS) (Fig. 1). The altitude of the HDSS is divided into high land, Midland, and low land climatic conditions. According to the Woreda health office reports, the district has six health centers, three health stations, and thirty-one health posts that provide health services to the community. The total population of the district was estimated to be 158, 250 of whom 70, 611 people were the population of the HDSS with almost 1:1 sex ratio. The DHSS has 7918 children under the age of 5 years from 6314 households [13].

Study design and population: the community-based cross-sectional study was carried out among rural and urban households from April to December 2016. Mothers /caretakers with under-five children (6-59 months) and found in the HDSS were the study participants.

Data collection tool and data collection procedure: A pre-tested interviewer-administered structured questionnaire developed by the investigators in English language translated to local language was used to collect data on socio-demographic, health characteristics, child feeding characteristics and food preference habits of mothers /caretakers of the under-five children (Additional file 1). A five-day intensive training was provided for data collectors and supervisors. A pre-test was conducted in the rural and urban kebeles which are not included in the HDSS. The necessary modification was made on the tool according to the inputs obtained from the pre-test. Data were collected by 15 experienced data collectors and supervised by 5 supervisors working for Dabat HDSS.

Data processing and analysis: Data were entered into Epi data template prepared by the Amharic language to avoid data entry errors by five experienced data entry clerks working for Dabat HDSS. The data entry process was supervised by the data manager working for the HDSS. Entered data were transported to STATA version 12 for further analysis. Before the actual data analysis, 


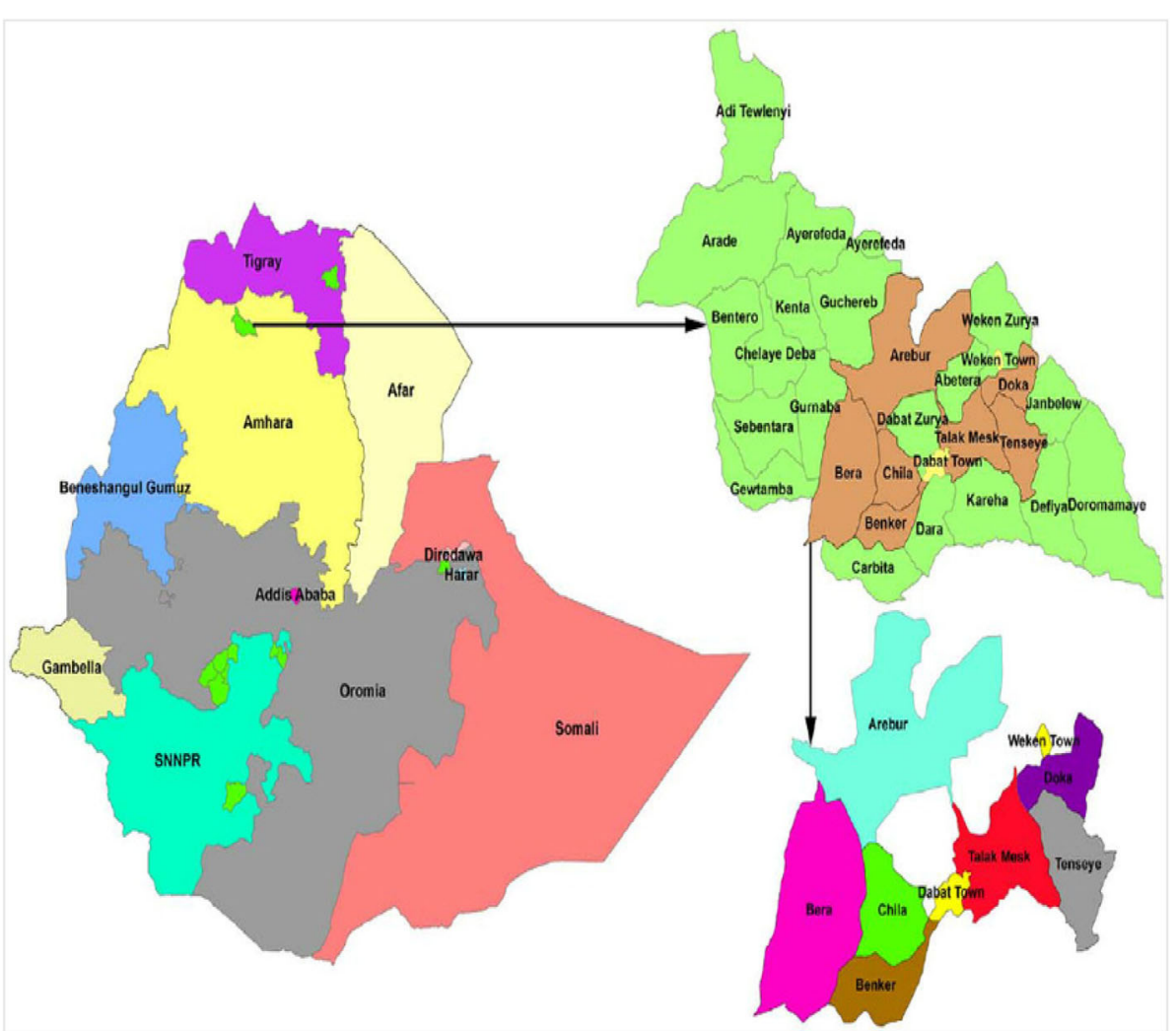

Fig. 1 The figure showing the maps of the nation, the region, the district and the kebeles included in the survey uploaded by Almayehu Worku available at http://www.biomedcentral.com/1471-2458/13/168

data clearance was performed. After data clearance and recoding, a multinomial logistic regression model was fitted to identify predictors for mothers/ caretakers preference to feed specific type of food, family food or balanced diet for their under-five children.

Dependent variable: Mothers/caretakers food preference for under- 5 year's children.

\section{Independent variables}

Socio-demographic characters: - (age and sex of the child, birth order and interval of the child, maternal educational status, parents educational status, family size, religion ethnicity, occupation).

Environmental factor: - (means of transportation, the distance of the market, food item buying habits and frequency, residence).

Health factors:- (child illness, PNC, ANC utilization, child immunization status).

\section{Operational definition}

Food preference: If parents choose to feed food with the same caloric content more than once per day it is considered as preferring to feed specific food preference, if they tend to feed any available food or the food prepared for adult family members it is considered as a preference to feed family food and if there is a habit of balancing child food from locally available food items it is a preference to feed a balanced diet.

\section{Result}

About 6896 participants were willing to respond for the interview making the response rate of $97.4 \%$. Almost half $(50.5 \%)$ of children were female. More than threefourths $(79.86 \%)$ and two-thirds $(68.00 \%)$ of mothers /caretakers were rural residents and farmers by occupation. Majority of mothers/caregivers (81.20\%) were Orthodox Christians and $86.29 \%$ were currently married. A large proportion (74.23\%) of households with under-five children had a garden to grow cereals and grains (Table 1).

\section{Mothers /caretakers food preference and feeding practice in Dabat district}

From the total $4313(62.55 \%)$ of mothers/caretakers prefers feed with the portion of family food and $1135(16.45 \%)$ of them prefers to feed their under-five children with a specific type of food more than once per day. Regarding balancing of child food from 
Table 1 Socio-demographic characteristics and feeding practice of under-five children in Dabat health and demographic surveillance system: Dabat district North West Ethiopia 2017

\begin{tabular}{|c|c|c|c|c|}
\hline Variable & Category & Frequency & Percentage & Remark \\
\hline \multirow[t]{2}{*}{ Sex } & Male & 3413 & 49.50 & \\
\hline & Female & 3483 & 50.50 & \\
\hline \multirow[t]{7}{*}{ Age } & $6-12$ months & 1025 & 14.95 & \\
\hline & 13-18 months & 728 & 10.43 & \\
\hline & 19-24 months & 794 & 11.54 & \\
\hline & 25-30 months & 726 & 10.39 & \\
\hline & $31-36$ months & 809 & 11.74 & \\
\hline & $37-42$ months & 657 & 9.57 & \\
\hline & $43-50$ months & 2157 & 31.39 & \\
\hline \multirow[t]{5}{*}{ Birth order } & First birth & 1322 & 19.17 & \\
\hline & Second birth & 1,141 & 16.54 & \\
\hline & Third birth & 1,055 & 15.29 & \\
\hline & Fourth birth & 1021 & 14.82 & \\
\hline & Fifth and above & 2357 & 34.17 & \\
\hline \multirow[t]{5}{*}{ Birth interval } & One year & 235 & 3.41 & \\
\hline & Two years & 1429 & 20.72 & \\
\hline & Three years & 2605 & 37.78 & \\
\hline & Fourth years & 1229 & 17.82 & \\
\hline & Five year & 1398 & 20.27 & \\
\hline \multirow[t]{2}{*}{ Source of food items } & Garden & 5119 & 74.23 & \\
\hline & Market & 1777 & 25.77 & \\
\hline \multirow[t]{5}{*}{ Available food items } & Fruit and vegetables & 2276 & 32.53 & \\
\hline & All types of meat & 5432 & 77.63 & \\
\hline & Egg and milk & 4750 & 67.89 & \\
\hline & Cereal and grains & 6797 & 97.14 & \\
\hline & Root and tubers & 247 & 3.53 & \\
\hline \multirow[t]{3}{*}{ Relation of caregivers } & Mother & 6589 & 95.55 & \\
\hline & Grandmother & 218 & 3.15 & \\
\hline & Father and other relatives & 89 & 2.22 & \\
\hline \multirow[t]{2}{*}{ Preparation of child food } & Separately for children & 1624 & 23.55 & \\
\hline & With adults & 5272 & 76.45 & \\
\hline \multirow[t]{5}{*}{ Child feeding practice } & Alone & 4205 & 60.97 & \\
\hline & With older children & 967 & 14.02 & \\
\hline & With adults & 1678 & 24.33 & \\
\hline & Before adults and older children & 9 & 0.13 & \\
\hline & After adults and older children & 37 & 0.54 & \\
\hline \multirow[t]{4}{*}{ a distance of the nearby market } & $1-4 \mathrm{~km}$ & 1350 & 75.99 & \\
\hline & $5-10 \mathrm{~km}$ & 49 & 2.79 & \\
\hline & $11-20 \mathrm{~km}$ & 109 & 6.11 & \\
\hline & $\geq 21 \mathrm{~km}$ & 269 & 15.10 & \\
\hline \multirow[t]{3}{*}{ Frequency of food buying } & Daily & 45 & 2 & \\
\hline & 2-3 times per week & 172 & 7.6 & \\
\hline & Weekly & 574 & 25.3 & \\
\hline
\end{tabular}


Table 1 Socio-demographic characteristics and feeding practice of under-five children in Dabat health and demographic surveillance system: Dabat district North West Ethiopia 2017 (Continued)

\begin{tabular}{|c|c|c|c|c|}
\hline Variable & Category & Frequency & Percentage & Remark \\
\hline & One in two weeks & 332 & 14.66 & \\
\hline & Once per month & 1022 & 45.1 & \\
\hline & Once in four months & 122 & 5.4 & \\
\hline \multirow[t]{2}{*}{ Means of transportation to market } & Foot & 1770 & 99.60 & \\
\hline & Public transport & 7 & 0.40 & \\
\hline \multirow[t]{3}{*}{ Maternal education } & Unable to read and write & 4794 & 69.52 & \\
\hline & Primary education & 1406 & 20.39 & \\
\hline & Secondary and above & 696 & 10.09 & \\
\hline \multirow[t]{2}{*}{ Residence } & Rural & 5507 & 79.86 & \\
\hline & Urban & 1389 & 20.14 & \\
\hline \multirow[t]{3}{*}{ Ethnicity } & Amhara & 5470 & 79.33 & \\
\hline & Tigery & 1176 & 17.05 & \\
\hline & Others & 250 & 3.62 & \\
\hline \multirow[t]{3}{*}{ Religion } & Orthodox & 5599 & 81.20 & \\
\hline & Muslim & 1176 & 17.05 & \\
\hline & Others & 121 & 1.75 & \\
\hline \multirow[t]{4}{*}{ Maternal Occupation } & Farmer & 4689 & 68.00 & \\
\hline & Merchant/employed & 234 & 3.39 & \\
\hline & Housewife & 1514 & 21.96 & \\
\hline & Others & 459 & 6.65 & \\
\hline \multirow[t]{3}{*}{ Marital status } & Married & 5950 & 86.29 & \\
\hline & No married & 638 & 9.24 & \\
\hline & Separated /divorced & 308 & 4.47 & \\
\hline
\end{tabular}

locally available food items 1448 (21\%) of mothers/ caretakers prefer to feed a balanced diet food for under-five children (Table 2).

Factors associated with food preference among parents of under-five children Dabat HDSS

Among variables entered in to univariate multinomial logistic regression maternal religion, maternal inability to read and write 2.19(1.09-4.40), introducing semisolid food after six months $1.10(1.02-1.16)$, feeding child once in $24 \mathrm{~h}$ CORRR $=2.65(\mathrm{CI}=1.52-4.62)$, child age of 25-36 months CORRR $=1.29(\mathrm{CI}=1.05-1.57)$, one ANC visit during pregnancy CORRR $=2.07(\mathrm{CI}=1.39$ 3.07) were associated with increased odds of preferring family food for the child. While attending ANC in hospital CORR $=3.44(\mathrm{CI}=1.61-7.37)$ obtaining food from market CORR $=4.23(\mathrm{CI}=3.47-5.14)$ and having five and above ANC visit during pregnancy CORR $=1.83(\mathrm{CI}$ $=1.30-2.58$ ) were associated with increased odds of preferring a specific type of food for the children.

As shown in Table 3 maternal inability to read and write $A R R R=2.19(\mathrm{CI}=1.09-4.40)$, introducing semisolid food after 6 months ARRR $=2.34(\mathrm{CI}=1.50-3.96)$, and residing more than $4 \mathrm{kms}$ from a local market ARRR $=2.41(\mathrm{CI}=1.97-2.96)$ were associated with increased odds of preferring to feed a child with the family food. Similarly introducing semisolid food after 6 months 6.53(3.8-11.24), and obtain food from market ARRR = $4.38(\mathrm{CI}=3.45-5.56)$ were associated with the increased odds of preferring to feed specific type of food for the children (Table 3).

\section{Discussion}

Diversification and balancing of food are the strategies to address the nutritional problem of children. In this study, only $21 \%$ of mothers/caretakers prefer to feed a balanced diet, $62.55 \%$ of prefers to feed family food and $16.45 \%$ prefers to feed specific type of food for children. Preferring to feed children with family and specific type of food imply child malnutrition as it harms dietary diversity and dietary frequency contributors for child malnutrition $[14,15]$. This explanation was supported by evidence that reported the possibility of reducing the odds of stunting with increased dietary diversity [1621]. In our study area, child malnutrition is a major problem where $40,9,25 \%$ of children were stunted 
Table 2 Distribution of mothers/caretakers food preference with socio-demographic attributes: Dabat HDSS North West Ethiopia, 2017

\begin{tabular}{|c|c|c|c|c|}
\hline \multirow[t]{2}{*}{ Variables } & \multicolumn{4}{|l|}{ Food/feeding preference } \\
\hline & No preference/family food & Specific food preference & Balanced diet & Total \\
\hline \multicolumn{5}{|l|}{$\overline{\text { Age }}$} \\
\hline First year & 581 & 199 & 227 & 1007 \\
\hline Second year & 945 & 285 & 307 & 1537 \\
\hline Third year & 1000 & 248 & 303 & 1551 \\
\hline Fourth year & 1155 & 275 & 375 & 1805 \\
\hline Fifth year & 676 & 137 & 250 & 1063 \\
\hline Total & 4357 & 1144 & 1462 & 6963 \\
\hline \multicolumn{5}{|l|}{ Sex } \\
\hline Male & 2151 & 569 & 724 & 3444 \\
\hline Female & 2212 & 578 & 735 & 3525 \\
\hline Total & 4363 & 1147 & 1459 & 6969 \\
\hline \multicolumn{5}{|l|}{ Birth order } \\
\hline First order & 789 & 272 & 286 & 1347 \\
\hline Second order & 701 & 207 & 236 & 1144 \\
\hline Third order & 670 & 164 & 220 & 1054 \\
\hline Fourth order & 649 & 149 & 221 & 1019 \\
\hline Five \& above & 1531 & 344 & 500 & 2375 \\
\hline Total & 4340 & 1136 & 1463 & 6939 \\
\hline \multicolumn{5}{|c|}{ Introduction of supplementary food } \\
\hline$<6$ months & 115 & 109 & 313 & 537 \\
\hline At six month & 688 & 876 & 2489 & 4053 \\
\hline 7-11 months & 182 & 179 & 634 & 995 \\
\hline At one year & 121 & 268 & 747 & 1136 \\
\hline After one year & 30 & 27 & 129 & 186 \\
\hline uncertain & 7 & 0 & 37 & 44 \\
\hline Total & 1143 & 1459 & 4349 & 6951 \\
\hline \multicolumn{5}{|l|}{ ANC visit } \\
\hline one \&two visit & 682 & 163 & 239 & 1084 \\
\hline three visits & 1001 & 251 & 388 & 1640 \\
\hline four visits & 761 & 271 & 297 & 1329 \\
\hline Five \&above & 265 & 129 & 77 & 471 \\
\hline No ANC visit & 1623 & 316 & 452 & 2391 \\
\hline Total & 4332 & 1130 & 1453 & 6915 \\
\hline
\end{tabular}

wasted and underweight respectively that may be mainly attributed by inappropriate food preference by mothers/caretakers evidenced by the result of this study [22].

In this study area, about $68 \%$ of participants were farmers who have two possible options to feed their under-five children. The first option is feeding children as adult members in the morning and at night, difficult to attain minimum acceptable food diversity and frequency issues strongly associated with increased odds of child malnutrition [18, 23]. The second option would be a takeover of cooked food to the farmland and feeding the child the whole day the takeover food. These options have to be questioned against its safety which worsens their health condition another issue which has strong implication child malnutrition [23-28].

Mothers/caretakers who were unable to read and write, introduce semisolid food after 6 months and 
Table 3 Multinomial logistic regression table showing factors associated with parents/caretakers food preference to feed under-five year's children in Dabat HDSS; Dabat district northwest Ethiopia: 2017

\begin{tabular}{|c|c|c|c|c|c|c|}
\hline \multirow{3}{*}{$\begin{array}{l}\text { Predictor /variable } \\
\text { Religion }\end{array}$} & \multicolumn{6}{|c|}{ Base outcome balanced diet preference } \\
\hline & \multicolumn{3}{|c|}{ Family food preference } & \multicolumn{3}{|c|}{ Specific type of food } \\
\hline & Number & CRRR $(95 \% \mathrm{Cl})$ & $\operatorname{ARRR}(95 \% \mathrm{Cl})$ & Number & CRRR $(95 \% \mathrm{Cl})$ & $\operatorname{ARRR}(95 \% \mathrm{Cl})$ \\
\hline Orthodox & 3094 & 1.00 & 1.00 & 759 & 1.00 & 1.00 \\
\hline Muslim & 473 & $0.84(0.7-1.01)$ & $0.54(0.11-2.82)$ & 166 & $1.20(0.95-1.51)$ & $0.67(011-4.53)$ \\
\hline Others & 58 & $2.40(1.125 .02)^{*}$ & $0.45(0.03-5.37)$ & 39 & $6.55(3.04-14.11)$ & $1.23(0.07-20.66)$ \\
\hline \multicolumn{7}{|l|}{ Maternal EDU } \\
\hline Unable to read \& write & 1632 & $1.60(1.20-2.08)$ & $2.19(1.09-4.40)^{* *}$ & 453 & $0.08(0.58-1.10)$ & $1.24(0.53-2.89)$ \\
\hline Primary EDU & 445 & $1.30(0.94-1.77)$ & $1.42(0.69-2.92)$ & 130 & $0.70(0.48-1.10)$ & $0.88(0.37-2.14)$ \\
\hline Secondary+ & 182 & 1.00 & 1.00 & 99 & 1.00 & 1.00 \\
\hline \multicolumn{7}{|l|}{ Occupation } \\
\hline Farmer & 1592 & 1.00 & 1.00 & 474 & 1.00 & 1.00 \\
\hline Merchant & 30 & $0.47(0.26-0.85)$ & $0.88(0.25-3.17)$ & 4 & $0.21(0.07-0.63)^{*}$ & $0.32(0.05-2.06)$ \\
\hline Employed & 37 & $2.23(0.87-5.70)$ & $6.53(0.83-51.60)$ & 26 & $5.25(2.00-13.8)^{*}$ & $4.80(0.51-44.89)$ \\
\hline House wife & 469 & $0.81(0.66-0.99)$ & $0.71(0.39-1.28)$ & 117 & $0.68(0.52-0.88)^{*}$ & $0.64(0.29-1.38)$ \\
\hline Others & 131 & $0.76(0.54-1.06)$ & $1.22(0.55-2.72)$ & 61 & $1.18(0.80-1.75)$ & $1.08(0.41-2.89)$ \\
\hline Period of excusive BF & 4287 & $0.99(0.93-1.06)$ & $0.42(0.26-0.66)^{* *}$ & 1113 & $0.70(0.64-0.76)^{*}$ & $0.13(0.26-0.66)$ \\
\hline Period of breast feeding & 2060 & $0.89(0.78-1.01)$ & $0.80(0.64-0.96)^{* *}$ & 526 & $0.72(0.62-0.85)^{*}$ & $0.66(0.07-0.84)^{* *}$ \\
\hline Age at intr.of food & 4345 & $1.10(1.02-1.16)^{*}$ & $2.34(1.50-3.96)^{* *}$ & 11,138 & $0.90(0.83-0.98)^{*}$ & $6.53(3.8-11.24)^{* *}$ \\
\hline \multicolumn{7}{|c|}{ Frequency of feeding per $24 \mathrm{~h}$} \\
\hline Zero times & 91 & $0.92(0.63-1.36)$ & $0.76(0.19-3.05)$ & 32 & 1.07(0. .66-1.75) & $0.80(0.21-3.13)$ \\
\hline One & 98 & $2.65(1.52-4.62)^{*}$ & $2.82(0.77-10.36)$ & 37 & $3.32(1.79-6.14)^{*}$ & $3.52(0.98-12.61)$ \\
\hline Twice & 351 & $1.37(1.07-1.75)^{*}$ & $1.71(0.76-3.85)$ & 115 & $1.48(1.10-2.00)^{*}$ & $2.15(0.97-4.75)$ \\
\hline Three time & 1307 & $0.88(0.76-1.02)$ & $0.99(0.62-1.60)$ & 328 & $0.73(0.60-0.88)^{*}$ & $1.10(0.69-1.75)$ \\
\hline Four time & 1152 & 1.00 & 1.00 & 348 & 1.00 & 1.00 \\
\hline Five and above & 1354 & $2.38(1.20-2.84)^{*}$ & $1.38(0.80-2.38)$ & 283 & $1.65(1.32-2.05)^{*}$ & $1.46(0.85-2.47)$ \\
\hline \multicolumn{7}{|l|}{ Birth order } \\
\hline First & 792 & 1.00 & 1.00 & 271 & 1.00 & 1.00 \\
\hline Second & 699 & $1.07(0.88-1.31)$ & $1.63(0.24-11.25)$ & 207 & $0.93(0.72-1.91)$ & $1.81(0.13-25.33)$ \\
\hline Third & 671 & $1.09(0.89-1.34)$ & $1.38-0.20-9.54$ & 164 & $0.78(0.60-1.01)^{*}$ & $1.04(.07-14.79)$ \\
\hline Fourth & 647 & $1.07(0.87-1.34)$ & $0.92(0.13-6.43)$ & 149 & $0.72(0.55-0.94) *$ & $0.78(0.05-11.1)$ \\
\hline Fifth & 564 & $0.99(0.81-1.23)$ & $1.16(0.16-8.11)$ & 126 & $0.65(0.49-0.86) *$ & $0.57(0.04-8.29)$ \\
\hline Six and above & 975 & $1.17(0.97-1.41)$ & $1.75(0.25-12.18)$ & 218 & $0.76(0.60-0.97) *$ & $1.4(0.09-19.68)$ \\
\hline \multicolumn{7}{|l|}{ Age of the child } \\
\hline $6-12$ months & 581 & 1.00 & 1.00 & 199 & 1.00 & 1.00 \\
\hline 13-24 months & 925 & $1.13(0.91-1.39)$ & $0.81(0.44-1.51)$ & 285 & $0.98(0.75-1.27)$ & $0.81(0.43-1.51)$ \\
\hline $25-36$ months & 1000 & $1.29(1.05-1.57)^{*}$ & $0.83(0.44-1.56)$ & 248 & $0.93(0.93-1.20)$ & $0.83(0.44-1.56)$ \\
\hline 37-48 months & 1060 & $1.20(0.98-1.45)$ & $0.68(0.35-1.30)$ & 252 & $0.83(0.64-1.06)$ & $0.68(0.35-1.30)$ \\
\hline 49-60 months & 771 & $1.08(0.88-1.33)$ & $1.19(0.56-2.52)$ & 160 & $0.65(0.50-0.86)^{*}$ & $1.19(0.56-2.52)$ \\
\hline \multicolumn{7}{|c|}{$\Pi$ vaccination during pregnancy } \\
\hline Yes & 2150 & $0.69(0.41-1.18)$ & $1.36(0.42-4.36)$ & 623 & $0.56(0.30-1.05)$ & $1.36(0.42-4.36)$ \\
\hline No & 486 & $0.43(0 . .25-0.75)^{*}$ & $1.03(0.31-3.47)$ & 174 & $0.43(0.22-0.83)^{*}$ & $1.03(0.31-3.47)$ \\
\hline I don't know & 73 & 1.00 & 1.00 & 26 & 1.00 & 1.00 \\
\hline
\end{tabular}

Iron tablet supplementation during pregnancy 
Table 3 Multinomial logistic regression table showing factors associated with parents/caretakers food preference to feed under-five year's children in Dabat HDSS; Dabat district northwest Ethiopia: 2017 (Continued)

\begin{tabular}{|c|c|c|c|c|c|c|}
\hline \multirow[b]{2}{*}{ Yes } & \multicolumn{6}{|c|}{ Base outcome balanced diet preference } \\
\hline & 2392 & $0.88(0.69-1.11)$ & $1.16(0.67-2.03)$ & 708 & $0.73(0.54-0.96)^{*}$ & $1.16(0.67-2.03)$ \\
\hline No & 311 & 1.00 & 1.00 & 112 & 1.00 & 1.00 \\
\hline \multicolumn{7}{|l|}{ ANC Visit during pregnancy } \\
\hline No visit & 1656 & $1.42(1.20-1.68)^{*}$ & $0.99(0.63-1.57)$ & 331 & $0.80(0.64-0.99) *$ & $0.88(0.48-1.58)$ \\
\hline One visit & 173 & $2.07(1.39-3.07)^{*}$ & $1.47(0.61-3.55)$ & 37 & $1.25(0.76-205)$ & $0.82(0.25-2.67)$ \\
\hline two visits & 512 & $0.98(0.79-1.21)$ & $0.99(0.57-1.72)$ & 126 & $0.68(0.51-0.90) *$ & $0.89(0.43-1.85)$ \\
\hline three visits & 999 & $1.02(0.86-1.22)$ & $0.67(0.47-1.24)$ & 253 & $0.73(0.58-0.92) *$ & $0.96(0.52-1.79)$ \\
\hline four visits & 762 & 1.00 & 1.00 & 270 & 1.00 & 1.00 \\
\hline Five and above & 240 & 1.39(1.03-1.88) & $0.82(0.37-1.75)$ & 112 & $1.83(1.30-2.58) *$ & $1.25(0.48-3.25)$ \\
\hline \multicolumn{7}{|c|}{ Place of ANC visit during pregnancy } \\
\hline Health center & 2349 & $0.63(0.49-0.82)^{*}$ & $1.25(0.43-3.67)$ & 699 & $0.70(0.50-0.96)^{*}$ & $1.25(0.43-3.67)$ \\
\hline Health post & 318 & 1.00 & 1.00 & 86 & 1.00 & 1.00 \\
\hline Hospital & 35 & $0.86(0.41-1.81)$ & $2.84(0.65-12.32)$ & 338 & $3.44(1.61-7.37)^{*}$ & $2.84(0.65-12.32)$ \\
\hline \multicolumn{7}{|l|}{ Birth interval } \\
\hline One year & 125 & $1.03(0.68-1.54)$ & $0.59(0.20-1.69)$ & 30 & $1.60(0.62-1.08)$ & $0.59(0.15-2.36)$ \\
\hline Two years & 764 & 1.00 & 1.00 & 178 & 1.00 & 1.00 \\
\hline Three years & 1282 & $0.69(0.58-0.83)^{*}$ & $0.55(0.37-0.81)^{* *}$ & 312 & $0.72(0.57-0.92) *$ & $0.64(0.39-1.05)$ \\
\hline Four years & 628 & $0.78(0.63-0.97)^{*}$ & $0.73(0.45-1.18)$ & 130 & $0.69(0.52-0.93) *$ & $0.61(0.32-1.15)$ \\
\hline Five and above & 730 & $1.07(0.86-1.33)$ & $1.03(0.60-1.75)$ & 203 & $1.27(0.96-1.96)$ & $0.78(0.40-1.54)$ \\
\hline \multicolumn{7}{|c|}{ Obtaining food items from garden } \\
\hline Yes & 2968 & 1.00 & 1.00 & 625 & 1.00 & 1.00 \\
\hline No & 1047 & $2.19(1.86-2.59)^{*}$ & $2.41(1.97-2.96)^{* *}$ & 424 & $4.23(3.47-5.14)^{*}$ & $4.38(3.45-5.56)^{* *}$ \\
\hline \multicolumn{7}{|c|}{ Frequency of buying food items } \\
\hline Daily & 24 & 1.00 & $0.75(0.23-2.41)$ & 17 & 1.00 & $1.07(0.32-3.55)$ \\
\hline 2-3 per week & 76 & $0.37(0.12-1.15)$ & $0.36(0.18-0.61)^{* *}$ & 59 & $0.41(0.13-1.31)$ & $0.39(0.21-0.74)^{* *}$ \\
\hline Weekly & 330 & $1.02(0.34-3.05)$ & $0.57(0.35-0.94)^{* *}$ & 184 & $0.80(0.26-2.48)$ & $0.88(0.52-1.48)$ \\
\hline In two weeks & 201 & $0.44(0.15-1.31)$ & $0.23(0.14-0.38)^{* *}$ & 53 & $0.16(.05-0.51)^{*}$ & $0.21(0.12-0.38)^{* *}$ \\
\hline Monthly & 739 & $1.81(0.61-5.37)$ & 1.00 & 203 & $0.70(0.23-2.16)$ & 1.00 \\
\hline$>$ a month & 88 & $1.46(0.42-5.08)$ & $0.67(0.26-1.76)$ & 23 & $0.54(0.14-2.02)$ & $0.75(0.27-2.10)$ \\
\hline Distance to local market & 1465 & $1.57(1.39-1.78)^{*}$ & $1.41(1.17-1.70)^{* *}$ & 541 & $1.09(0.95-1.25)$ & $0.96(0.77-1.20)$ \\
\hline
\end{tabular}

* Significant at univariate model with $p$-value $<0.005$

** significant at multivariate model with $\mathrm{p}$-value $<0.00 \mathrm{~s}$

EDU educational status

Intro introduction

walk more than $4 \mathrm{kms}$ to market were $2.19(1.09-4.40)$, $2.34(1.50-3.96)$ and $1.41(1.17-1.70)$ times respectively more likely to prefer to feed their under-five children with a family food than balanced diet in this study. The association between the above three factors and feeding a child with a family food may be explained by the fact that those unable to read and write, introduce semisolid food before 6 months and walk more than $4 \mathrm{kms}$ to the market to obtain food would be unable to comply with appropriate child feeding recommendations due to the inaccessibility of health, nutritional or child food conditions which have implication for child malnutrition by interfering with safety, diversity, and frequency of child food [28].

Similarly, mothers/caretakers who introduce semisolid food after 6 months were and obtain food items from the market were 6.53(3.8-11.24) and 4.38(3.455.56) times more likely to feed specific type of food for under-five children than feeding with a balanced diet. The association of late introduction of semi-fluid food and preference to feed a child with a specific type of food may be due to miss understanding of child feeding 
practice as the main reason of preference to feed a specific type of food for about $53 \%$ of the participants in this study was improving child health. Similarly, positive association between walking a far distance to the market and preference feed a specific type of food may be due to the difficulty of buying diversified food frequently as almost all those who buy food in this study walks on foot to the market. Such specific food preference for any reason has a contribution for child malnutrition as it has a direct effect on reduced diversity of the child food evidenced Chinese study that showed to a reduced score of height for weight with reduced dietary diversity [29].

On the other hand, exclusively breastfeed a child for 6 months 58\% (34-74\%), breastfeed for 2 years 20\%(4-36\%) and having 3 years birth interval between births $45 \%(19-63 \%)$ were associated with a decreased odds of preferring to feed a child with family food. In all of the above cases, mothers/caretakers may be better informed about appropriate child feeding practice and family planning service strategies to address child malnutrition [30].

Continuing breastfeeding for 2 years $79 \%(62-88)$ and buy food in 2 weeks frequency 34\%(16-93\%) were also associated with the decreased odds of preferring to feed a child with the specific type of food. Inverse association between increased duration of breastfeeding and preferring to feed a child with a specific type of food may be due to having better information on child feeding practice which has a great contribution to reduce child malnutrition. Similarly, the inverse relationship between an increased frequency of food buying and preferring to feed balanced diets for children could be associated with better access to infrastructure and food security, the major contributor for better child nourishment [31].

The main limitation of the study was that data were collected only from mothers/caretakers where involvement of both parents may better supplement the evidence.

\section{Conclusions}

Despite the local availability of recommended diversity of food for the feeding of under-five children in the study are about $79 \%$ of mothers or caretakers of under-five children prefer to feed their children either family food (cooked for adult family) or a specific /monotonous/ type of food more than once a day having direct effect on reduction of dietary diversity, safety and acceptability of child food that intern might contribute for the increased and sustained prevalence of under-five malnutrition against efforts to reduce the magnitude in the study area and the nation at large. Therefore we recommended integration of child dietary diversity counseling session for mothers visiting health institution for ANC, PNC and immunization services and health professionals with IMNCI care and treatment guidelines.

\section{Additional files}

Additional file 1: English questionnaire. This questionnaire was developed by the authors to assess parent's food preference and its implication for child malnutrition in the study area. It has five parts that assess the sociodemographic, child health characteristics, maternal health characteristics, child feeding practice, and parents food preference sections. (DOCX $48 \mathrm{~kb}$ )

Additional file 2: Informed consent form. Informed consent form was prepared and attached at the front page of the questionnaire for participants to read and indicate their agreement or refusal for participating in this study. (DOCX $12 \mathrm{~kb}$ )

\section{Abbreviations}

ANC: Antenatal care; ARRR: Adjusted relative risk ratio; CRRR: Crude relative risk ratio; FAO: Food and Agricultural organization; HDSS: Health and Demographic Surveillance System; HIV/AIDS: Human immune virus/Acquired immunodeficiency syndrome; IQ: Intelligent Quotient; KM: Kilometer; MDG: Millennium Development Goal; PNC: Postnatal care

\section{Acknowledgments}

We acknowledge mothers/caretakers of under-five children and data collec tors, district health office managers for their participation in the study, hard work during data collection and support throughout the whole process of data collection respectively.

\section{Authors' contributions}

NBT Participated in the conception, design of the study, analyzed the data and drafted the manuscript. GAB, SMA and ME; interoperated the data, edited the manuscript and approved it for submission. All authors have read and approve the manuscript and ensure that this is the case.

\section{Author's information}

NBT: Ph.D. Student: - University of Gondar; college of medicine and health sciences institute of public health.

GAB: associate professor of public and child health; Director Institute of public health, University of Gondar.

SMA: associate professor of nutrition, coordinator of master card foundation, University of Gondar.

MEY: professor of nutrition university of Gondar.

Strength of the study: For assessment of mothers/caretakers food preference, the study considers a relatively large sample size and advanced statistical model.

\section{Funding}

The University of Gondar has funded the whole data collection and supervision activities of this project. The university has no any direct role in the design, and collection, analysis and interpretation of data except evaluation of expenditure of budget for the intended research activities.

\section{Availability of data and materials}

The datasets used and/or analyzed during the current study are available from the corresponding author on reasonable request.

\section{Ethics approval and consent to participate}

Ethical clearance was obtained from the Institutional Ethical Review Board (IRB) of the University of Gondar with the reference no of R.NO.ON/P/RCS/05/1220/ 2016. Written informed consent was obtained from the participants and the Objective, benefit, and risk of the study were explained for the participants (Additional file 2). Besides, data collectors were instructed to assure the rights of the respondents to refuse or withdraw from the interview at any time without any form of prejudice. Children with undernutrition (mid-upper arm circumference $(\mathrm{MUAC})=11.5 \mathrm{~cm}$ or yellow), anemia and intestinal parasitosis were referred to nearest health facilities and health/nutritional education was also given to parents/caretakers by data collectors and supervisors.

Confidentiality of the information was maintained by coding of all personal or household identifiers. 


\section{Competing interests}

The authors declare that they have no competing interests.

\section{Author details}

${ }^{1}$ School of Nursing, College of Medicine and Health Sciences, University of Gondar, Gondar, Ethiopia. ${ }^{2}$ Department of Health Service Management and Health Economics, Institute of Public Health, College of Medicine and Health Sciences, University of Gondar, Gondar, Ethiopia. ${ }^{3}$ Department of Human Nutrition, Institute of Public Health, College of Medicine and Health Sciences, University of Gondar, Gondar, Ethiopia.

\section{Received: 19 December 2018 Accepted: 26 August 2019}

Published online: 02 September 2019

\section{References}

1. Fanzo J. The Nutrition Challenge in Sub-Saharan Africa united nations development program regional for Africa. 2012. p. 1-3.

2. Sally Grantham-McGregor YBC, Cueto S, Glewwe P, Richter L, Strupp B. Developmental potential in the first 5 years for children in developing countries. Lancet. 2007:369:60-70.

3. Children st. a life free from hunger, tackling child malnutrition report 2012.

4. UNESCO. On the road to Education for All: Progress and challenges report 2010

5. Haddad L. Ending Undernutrition: Our Legacy to the Post 2015 Generation. children investment fund May 2013

6. Wilson Were BD, Bahl R, Bhutta Z, Qazi S, Willumsen J, Young M, Starbuck E, Merso M. Child health priorities, and interventions report; 2015. p. 1-14.

7. Oruamabo RS. Child malnutrition and the Millennium Development Goals: much haste but less speed? BJM. 2014;100:19-22.

8. UNICEF. IMPROVING CHILD NUTRITION, The achievable imperative for a global progress report in April 2013

9. Estimates WhoU-W-TWBjcm. Levels and trends in child malnutrition. 2012(978 92 4,150,451 5)

10. UNICEF LTiCMr. Levels \& Trends in Child Malnutrition report 2012

11. Team Ust. Imagining a world free from hunger: Ending hunger and malnutrition and ensuring food and nutrition security; 2012. p. 1-9.

12. Fanzo J. The Nutrition Challenge in Sub-Saharan Africa. united nations development program working paper January 2012 1-3.

13. Tadesse TGA, Admassu M, Yigzaw Kebede Y, Awoke T, Tesfahun Melese T. Demographic and health survey at dabat district in northwest Ethiopia: report of the 2008 baseline survey. Ethiop J Health Biomed Sci. 2011;4:1-23.

14. Tefera Chane Mekonnen caSBW, 2 Tesfa Mekonen Yimer,3 and Wubalem Fekadu Mersha. Meal frequency and dietary diversity feeding practices among children 6-23 months of age in Wolaita Sodo town, Southern Ethiopia. J Health Popul Nutr. 2017;36:18.

15. WHO. Indicators For Assessing Infant And Young Child Feeding Practices 2007.

16. Chau Darapheak TT, Kizuki M, Nakamura K, Seino K. Consumption of animal source foods and dietary diversity reduce stunting in children in Cambodia. Int Arch Med. 2013;6:29.

17. Rah JH AN, Semba RD, de Pee S, Bloem MW, Campbell AA, Moench-Pfanne R, Sun K, Badham J, Kraemer K. Low dietary diversity is a predictor of child stunting in rural Bangladesh. Eur J Clin Nutr. 2010;64(12):1393-8.

18. Abigail Bentley SD, Alcock G, More NS, Pantvaidya S, Osrin D. Malnutrition and infant and young child feeding in informal settlements in Mumbai, India: findings from a census. Food Sci Nutr. 2015:3(3):257-71.

19. Steyn NP, de Villiers A, Gwebushe N, Draper CE, Hill J, de Waal M, Dalais L, Abrahams Z, Lombard C, Lambert EV. Did HealthKick, a randomized controlled trial primary school nutrition intervention improve the dietary quality of children in low-income settings in South Africa? BMC Public Health. 2015;15(948):2282-4.

20. Ph SB, JFP D, MSc SS. Feeding practices among Indonesian children above 6 months of age: a literature review on their magnitude and quality. Asia Pacific J Clin Nutr. 2015;24(1):16-27.

21. Basit ANS, Chakraborthy KB, Darshan BB, Kamath A. Risk factors for Undernutrition among children aged one to 5 years in Udupi taluk of Karnataka, India: A case-control study. Australas Med J. 2012;5(3):163-7.

22. Ethiopia] CSA. Ethiopia Mini Demographic and Health Survey 2014. Addis Ababa, Ethiopia. 2014

23. Teshome B, WK-M ZG, Taye G. Magnitude and determinants of stunting in children under 5 years of age in food surplus region of Ethiopia: The case of West Gojam Zone. Ethiop J Health Dev. 2009;23(2):99-106.
24. TZaD A. Determinants of Child Malnutrition: Empirical Evidence from Kombolcha District of Eastern Hararghe Zone, Ethiopia. Q J Int Agric. 2013; 52(4):357-72.

25. OIJCP T. Factors influencing the pattern of malnutrition among acutely ill children presenting in a tertiary hospital in Nigeria. Niger J Paed. 2014:41(4):326-30.

26. Nhampossa T, Sigaúque B, Machevo S, Macete E, Alonso P, Bassat $Q$, Menéndez C, Fumadó V. Severe malnutrition among children under the age of 5 years admitted to a rural district hospital in southern Mozambique. Public Health Nutr. 2013;16(9):1565-74.

27. Benta A Abuya JC, Kimani-Murage E. Effect of mother's education on child's nutritional status in the slums of Nairobi. BMC Pediatrics. 2012;12:80.

28. Tamiru MW, Tolessa BE, Abera SF. Under Nutrition and Associated Factors Among Under-Five Age Children of Kunama Ethnic Groups in Tahtay Adiyabo Woreda, Tigray Regional State, Ethiopia: Community based study. Int J Nutr Food Sci. 2015;4(3):277-88.

29. Xue Y, Zhao A, Cai L, Yang B, Szeto IMY, Ma D, Zhang Y, Wang P. Growth and Development in Chinese Pre-Schoolers with Picky Eating Behaviour: A Cross-Sectional Study. PLoS ONE. 2015;10(4):e0123664. https://doi.org/10.13 71/journal.pone.0123664

30. Kodzi ØKI. Children's stunting in sub-Saharan Africa: Is there an externality effect of high fertility? Demogr Res. 2011:25:18.

31. Gabriela M Vedovato PJS, Jones-Smith J, Steeves EA, Han E, Trude ACB, Kharmats AY, Gittelsohn J. Food insecurity, overweight, and obesity among low-income African-American families in Baltimore City: associations with food-related perceptions. Public Health Nutr. 2015:19(8):1405-16.

\section{Publisher's Note}

Springer Nature remains neutral with regard to jurisdictional claims in published maps and institutional affiliations.

Ready to submit your research? Choose BMC and benefit from:

- fast, convenient online submission

- thorough peer review by experienced researchers in your field

- rapid publication on acceptance

- support for research data, including large and complex data types

- gold Open Access which fosters wider collaboration and increased citations

- maximum visibility for your research: over $100 \mathrm{M}$ website views per year

At BMC, research is always in progress.

Learn more biomedcentral.com/submission 